\title{
ARTIGO
}

COI https://doi.org/10.22481/praxisedu.v16i37.6172

\section{THE TEN MONTH INVESTIGATION AND EDUCATION FOR EFFECTING OF CORRECTIVE FEEDBACK FOR THE SECOND LANGUAGE (L2) PRAGMATICS IN IRAN}

\author{
LA INVESTIGACIÓN Y EDUCACIÓN DE DIEZ MESES PARA EFECTUAR LA \\ RETROALIMENTACIÓN CORRECTIVA PARA LA PRAGMÁTICA DEL SEGUNDO \\ IDIOMA (L2) EN IRÁN
}

A INVESTIGAÇÃO E EDUCAÇÃO DE DEZ MESES PARA OBTER FEEDBACK CORRETIVO PARA A PRAGMÁTICA DO SEGUNDO IDIOMA (L2) NO IRÃ

\author{
Farzaneh Sabokrouh \\ University college of Rouzbahan - Iran
}

Nasrin Shamsipour

Sharif University of Technology - Iran

Vahideh Rastgoo

Islamic Azad University - Iran

\begin{abstract}
Feedback is any information provided about the accuracy and appropriateness of a response. To determine the effect of feedback in native and Persian language on reading and writing in bilingual (Kurdish-Farsi) students, 45 elementary school students were selected by cluster sampling method in Iran. In this paper, Students were divided into three distinct groups: the first experimental group receiving feedback in their native language, the second experimental group receiving feedback in native language, and the control group receiving no feedback. A researcher-designed test of academic achievement was used to collect the data. The results of covariance analysis showed that providing feedback in native language had a significant effect on the reading and writing of bilingual students and there was a significant difference between the first experimental group (receiving feedback in native language) and the control group (which did not receive feedback). . But there was no significant difference between the second experimental group (received feedback in Farsi) and the control group. These findings showed that providing feedback in Farsi language did not significantly influence bilingual students' reading and writing progress. Based on the findings of the present study, it can be concluded that providing native language feedback to bilingual students can be effective in improving their performance.
\end{abstract}

Keywords: email requests, syntactic downgraders, corrective feedback, L2 pragmatic competence 
Resumen: La retroalimentación es cualquier información proporcionada sobre la precisión y la idoneidad de una respuesta. Para determinar el efecto de la retroalimentación en lengua nativa y persa en la lectura y escritura en estudiantes bilingües (kurdos-farsi), se seleccionaron 45 estudiantes de primaria mediante el método de muestreo por conglomerados en Irán. En este documento, los estudiantes se dividieron en tres grupos distintos: el primer grupo experimental que recibió comentarios en su idioma nativo, el segundo grupo experimental que recibió comentarios en idioma nativo y el grupo de control que no recibió comentarios. Se utilizó una prueba de rendimiento académico diseñada por un investigador para recopilar los datos. Los resultados del análisis de covarianza mostraron que proporcionar retroalimentación en el idioma nativo tuvo un efecto significativo en la lectura y escritura de los estudiantes bilingües y hubo una diferencia significativa entre el primer grupo experimental (que recibió retroalimentación en el idioma nativo) y el grupo de control (que no recibir comentarios). . Pero no hubo diferencias significativas entre el segundo grupo experimental (recibió retroalimentación en farsi) y el grupo de control. Estos hallazgos mostraron que proporcionar comentarios en idioma farsi no influyó significativamente en el progreso de lectura y escritura de los estudiantes bilingües. Con base en los hallazgos del presente estudio, se puede concluir que proporcionar comentarios sobre el idioma nativo a los estudiantes bilingües puede ser efectivo para mejorar su rendimiento.

Palabras clave: solicitudes por correo electrónico, downgraders sintácticos, retroalimentación correctiva, competencia pragmática L2

Resumo: Feedback é qualquer informação fornecida sobre a precisão e adequação de uma resposta. Para determinar o efeito do feedback na língua nativa e persa na leitura e escrita em estudantes bilíngues (curdos-farsos), 45 alunos do ensino fundamental foram selecionados pelo método de amostragem por cluster no Irã. Neste artigo, os alunos foram divididos em três grupos distintos: o primeiro grupo experimental recebendo feedback em seu idioma nativo, o segundo grupo experimental recebendo feedback em idioma nativo e o grupo controle sem feedback. Um teste de desempenho acadêmico projetado pelo pesquisador foi usado para coletar os dados. Os resultados da análise de covariância mostraram que o fornecimento de feedback na língua nativa teve um efeito significativo na leitura e escrita de estudantes bilíngues e houve uma diferença significativa entre o primeiro grupo experimental (recebendo feedback na língua nativa) e o grupo controle (que não apresentou receber feedback). . Mas não houve diferença significativa entre o segundo grupo experimental (feedback recebido em farsi) e o grupo controle. Essas descobertas mostraram que o fornecimento de feedback na língua farsi não influenciou significativamente o progresso da leitura e escrita dos alunos bilíngues. Com base nos resultados do presente estudo, pode-se concluir que fornecer feedback em idioma nativo para estudantes bilíngues pode ser eficaz para melhorar seu desempenho.

Palavras-chave: solicitações de e-mail, desatualizadores sintáticos, feedback corretivo, competência pragmática de L2

\section{Introduction}

The call for longitudinal research into the efficacy of written corrective feedback $(\mathrm{CF})$ can be traced back to the debate between Truscott and Ferris in the mid- to late 1990s. In 1996, Truscott claimed that error correction in ESL (English as a second language) writing 
programmes should be abandoned because it is ineffective and harmful. He claimed (i) that there was no research evidence to support the view that it ever helps student writers; (ii) that, as typically practised, it overlooks SLA (second language acquisition) insights about how different aspects of language are acquired; and (iii) that practical problems related to how teachers provide WCF and how students receive it to make a futile endeavour. As email requests from students to professors have become increasingly common in academic settings, research has also shown that second language (L2) students' unfamiliarity with email etiquette in the target language (TL) may adversely affect their communication with their professors (Akikawa and Ishihara 2010; Alcón-Soler 2013; Biesenbach-Lucas 2006; Biesenbach-Lucas 2007; C. Chen 2006; Economidou-Kogetsidis 2011; Félix-Brasdefer 2012; Hartford and Bardovi-Harlig 1996). Despite the need for these students to acquire L2 'email literacy', however, research into the effects of instruction on email pragmatics to inform classroom practices is extremely scarce (e. g. Alcón-Soler 2015; Nguyen et al 2015; Y. Chen 2015; Ford 2006). The purpose of this article is to explore the effects of an instructional technique, which is giving corrective feedback on L2 students' performance during pragmatics-focused classroom activities, on improving their ability to write pragmatically appropriate email requests to professors. In particular, we aim to examine the comparative longitudinal effects on learners' production of syntactically mitigated requests of four different types of written $\mathrm{CF}$, i. e. clarification requests, recasts, metalinguistic feedback, and explicit corrections accompanied by metalinguistic explanations. To date, the role of CF has been extensively investigated in L2 grammar studies and there is increasing evidence that CF can facilitate learning (see Ellis 2009; Li 2010; Lyster and Saito 2010; Lyster et al. 2013; Russell and Spada 2006; Sheen 2010a). Nevertheless, the topic has received much less attention in interlanguage (IL) pragmatics research (Lyster et al. 2013). Some L2 pragmatics studies have included CF as part of their instructional design but do not explicitly address its role (e. g. see Alcón-Soler 2008; Martínez-Flor et al. 2003; Rose and Kasper 2001). Given that relatively few studies have discussed pragmatic development in relation to CF alone (e. g. Nguyen et al 2015; Koike and Pearson 2005; Nipaspong and Chinokul 2010; Takimoto 2006; - see below), there is clearly a need to continue this line of research in order to achieve a more complete understanding of how different types of CF work in the pragmatic realm.

learning as a powerful tool for student learning (including Black, Harrison, Lee, Marshall, \& William, 2003; Hargreaves, 2001). Measurement for learning is different from the measurement of learning. Information is collected and used in the assessment position for 
learning for specific purposes and to help students progress. Alavi and Keyvanpanah (2003) have investigated the effect of feedback on the success rate of Iranian students in English language courses. For these researchers, success rates and educational levels have a significant impact on feedback expectation. The impact of video feedback training on internet communication skills of medical sciences university has also been investigated. According to the results of this study, video feedback training method has more effect on communication skills promotion than the conventional lecture method (Mogheb et al., 2010). The effect of teacher written classroom feedback on self-efficacy and math problem solving in middle school female students has been investigated (Samadi 2008). The results of this study reflect the fact that effective feedback methods are instructive and enhance learners' performance in the motivational and academic domains. Feedback is provided while the student is still receiving information and practicing skills. But since feedback, or knowledge of the results, is as important as the educational material itself, it must be assured that this knowledge is transmitted to students. Reports indicate that most students do not read written feedback on their test papers (Duncan, 2007). Some research has also highlighted the fact that teachers (as well as students) view feedback as a separate issue from other aspects of the teaching-learning process and regard it as a purely teacher-owned tool. In other words, feedback does not play a role in measuring learning and measuring learning (Taras, 2003). Now the question is why students don't read or apply teacher feedback? Is there a specific way of expressing feedback needed? Duncan (2007) believes that most students' homework opinions and perspectives make sense to the teacher, while they are not understood and understood, leading to a one-way feedback loop and "measuring for Learning "loses its effect. Like the books and educational materials that are organized on students' cognitive, emotional, and motor development at different levels, the feedback must also be consistent with the level of cognitive development, levels of understanding and understanding of the student, and his / her culture and ecological conditions. When we speak of culture and ecology we cannot escape from the language and dialectics. This is especially important in bilingual tissues. Bilingual students for a while do not even understand the role of the feedback informant. The limited vocabulary of the vocabulary does not allow them to grasp the concept of written or verbal feedback as a result of which no action is taken to compensate for their educational weaknesses and are virtually separated from the teaching process. This is where the credibility of education as a dynamic process is called into question (Kamali, 2009). The dynamic feedback system, or simply the teaching process, does not create logs and folders, but the teacher guides this process through his / her teaching style 
(Hosni \& Ahmadi, 2009). Sometimes there are situations where teacher feedback is not transmitted to the student for some reason or in other words, the expected educational and developmental purpose of the training is not met as it should be. As we have mentioned, one of the reasons for this may be the lack of knowledge and mastery of the student in the national (educational) language, and consequently his / her inability to understand the concepts presented in the teacher's oral or written feedback. Academic failure and bilingual students' performance are related to their bilingualism and different ways of teaching (Kalantari et al., 2011). The bilingual child is forced to learn the underlying skills of reading and writing in a language they are unfamiliar with (Sepehr, 2004). This action delays the speech phase in the child, and grammatical differences in language lead to mental disorder and disorder. Many research findings have revealed the decline in bilingual students' academic achievement (Ashare, 2003, 2009; Modarres, 2003; Kalantari, 2009; Karimi, 2005). In bilingual classes, where the student does not understand the concepts presented in the teacher feedback, there is a possibility of creating a defective cycle; disconnecting the student from the teaching process and consequently not understanding the teacher's interaction and disconnecting or neglecting the teacher, Assuming that he does not understand the concepts presented in the feedbacks (Squirrel, 2013; Baker, 2011). Declining education and bilingual students is a subject that our country is facing, like many countries in the world (Kalantari et al., 2011; Modares, 2009). It is assumed that providing positive oral feedback in the student's native language will make the learning process meaningful and link it to the education and classroom circles, which can ultimately lead to improved student learning and development. This study addresses the question of whether providing bilingual feedback in primary language bilingual classes can enhance its effectiveness as a measurement tool for learning when the student's understanding of the mother tongue is more than the official language.

\section{Materials and Methods}

200 pragmatics-focused instruction consisting of 20-40 year students studying in English language in Tehran (Capital of Iran). Average age of subjects was 18-25. 96 out of them were women, while 104 were men (Table 1 and Diagram 1). To say more precisely, 48\% of the respondents were women, $52 \%$ were men. 
Table 1. Gender composition of respondents

\begin{tabular}{|c|c|c|c|}
\hline Gender & cy Frequen & Percent & $\begin{array}{l}\text { Collecte } \\
\text { d percentage }\end{array}$ \\
\hline Woman & 96 & 48.0 & 48.0 \\
\hline Man & 104 & 52.0 & 100.0 \\
\hline Total & 200 & 100.0 & \\
\hline
\end{tabular}

\section{Diagram 1. Gender of respondents}

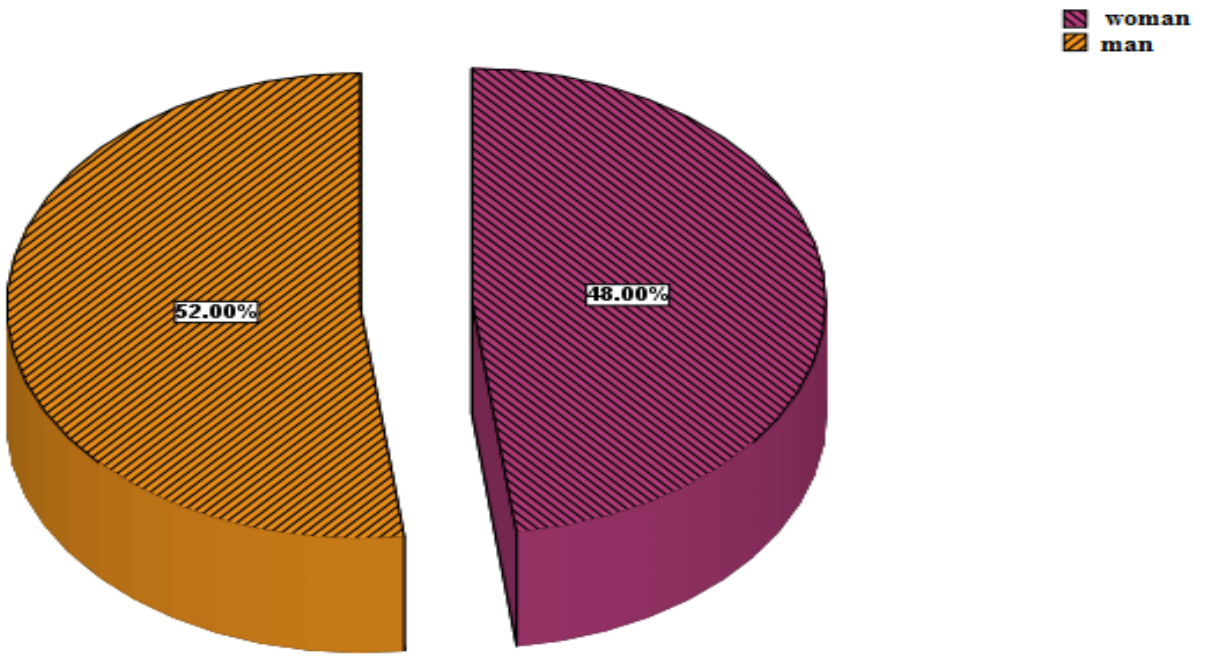

Aims

In line with the preceding literature review, our study is conducted to understand how the four types of $\mathrm{CF}$ traditionally investigated in the oral form such as clarification requests, metapragmatic feedback, recasts, and explicit corrections, when delivered in the written form, work for the acquisition of L2 pragmatic competence. In the oral CF literature, clarification requests and metapragmatic feedback are categorized as output-pushing $\mathrm{CF}$ while recasts and explicit corrections input-providing (Ellis 2006). The two categories differ in their theoretical underpinnings (i. e. cognitive-interactionist theories that argue for the role of input and noticing versus skill-acquisition theories that emphasize the role of output in consolidation of L2 knowledge) (see Lyster et al. 2013; Shintani et al. 2014). This distinction is understood to 
parallel that between indirect correction (i. e. CF providing only clues to prompt students to correct their own errors) and direct correction (i. e. CF involving the provision of correct answers) in the body of research on written CF (see Bitchener and Knoch 2008). To date, whereas L2 writing researchers have advocated indirect feedback since it is believed to afford opportunities for guided learning and problem-solving, SLA researchers have generally argued for the advantage of direct feedback, particularly when it is targeted at few selected features and addressed to less proficient learners (Ferris 2010; Shintani et al. 2014). As such, our study serves both theoretical and pedagogical purposes. Theoretically, it seeks to add further evidence on the relative effectiveness of the various subtypes of input-providing/ direct and outputpushing/ indirect CF when delivered in the written medium. CF delivered orally and in writing may differ in a number of dimensions (e. g. concerning the immediacy of delivery, the degree of explicitness, the cognitive load imposed on memory, the addressee of the $\mathrm{CF}$, and the opportunity for multiple corrections - see Sheen 2010b). Thus, we would expect that the four $\mathrm{CF}$ types outlined above may work differently when delivered in a different modality than is traditionally investigated. Pedagogically, the four CF types may differ in terms of the amount of time and effort required of the teacher. Therefore, understanding how these different ways of providing $\mathrm{CF}$ work relatively may inform teachers of the effective yet manageable CF types that are useful for their classroom practices. A further unique feature of our study is that the impact of the $\mathrm{CF}$ is measured over an extended duration of eight months. We ask how the four CF approaches contribute comparatively to improving L2 learners' use of syntactic downgraders to mitigate their email requests to professors and whether these effects last sufficiently long to recommend classroom pedagogy.

With the above purposes in mind, we seek to answer the following research questions:

(i) To what extent do learners who receive one of the following CF types - clarification requests, meta-pragmatic feedback, recasts and explicit corrections improve the frequency with which they employ syntactic downgraders to mitigate the force of their email requests addressing professors?

(ii) What are the comparative effects of the four CF types on the learners' frequency of use of syntactic downgraders when writing email requests to professors? 


\section{Design}

Accuracy in using two functions of the English article system was measured over a 10-month period by means of a pre-test-post-test design (a pre-test at the beginning of the 10month period and post-tests after 2 weeks, 2, 6 and 10 months). Fifty-two low-intermediate ESL learners were arbitrarily assigned to one of four groups: group 1 received direct error correction above each targeted error as well as written and oral meta-linguistic explanation; group 2 received direct error correction and written meta-linguistic explanation; group 3 received direct error correction; group 4 was the control group and therefore did not receive CF. Each group comprised of 13 students. The study examined the effect of these particular feedback options (variable combinations) as they are well-established practices used by ESL classroom teachers. In adopting this aspect of the design, we acknowledge the need for researchers also to examine the relative effects of single feedback variables.

\section{Context}

Three email request scenarios were selected as the focus of our study. These consisted of requests for a face-to-face appointment with the professor, requests for the professor's feedback on the 'work-in-progress' assignment attached and requests for extension of a due date of an assignment. The above three scenarios were chosen as they were considered common in student-professor communication but challenging to students (Biesenbach-Lucas 2007). The scenarios included the same P and D variables. In particular, the student and the professor have an unequal power $(+\mathrm{P})$ and familiar social ( $-\mathrm{D})$ relationship. However, the scenarios differed in their imposition levels, with requests for extension of a due date considered most imposing on the professor's freedom of action, then requests for feedback and finally requests for an appointment. Features taught included direct and conventionally indirect requests, politeness strategies including syntactic devices, as well as email discourse structure (see further detail in Nguyen et al 2015). These features were selected based on corpora of pragmatically appropriate email samples in Akikawa and Ishihara (2010) and Biesenbach-Lucas (2007). 


\section{Instructional procedures}

On top of the normal syllabus, a four week instruction plan with three major components was implemented for the four treatment groups, each receiving six hour teaching. The major components included consciousness-raising, explicit, meta-pragmatic explanation and communicative practice. Brief details of each component are described in Table 2 below. The four treatment groups received exactly the same instructional procedure and materials; the only difference was the type of CF provided on the learners' inaccurate and inappropriate language use (see Section 5.4). On the other hand, the control group did not receive any instruction on email requests in the three above scenarios or CF. However, they went through the normal syllabus where they received 50 minute explicit instruction of basic forms for making and softening requests (including the four types of downgraders in focus) in everyday and work-related situations. As part of the syllabus, the learners also completed a consciousness-raising task focusing on recognizing levels of formality and directness, which was followed by a production task. Except for the control group, which was taught by a different teacher, the four treatment groups were alternatively taught by two researchers, who were trained carefully in pragmatics-focused instruction. One taught all four treatment groups in the odd weeks, and the other taught these groups in the even weeks. This was to ensure minimal influences caused by possible differences in teaching styles. It should be noted that although it would have been more desirable if the control group had also been taught by the two researchers, this arrangement was not possible due to workload issues. In order to minimize the effect of having a different teacher to teach the control group, we made sure that the teacher of the control group closely followed our instructional protocol (i. e. to teach according to the normal syllabus and withhold the feedback treatment). We also ensured that the three teachers shared similar educational backgrounds, qualifications, and experiences. All the three teachers were trained EFL instructors and had been teaching EFL for at least two years. Nonetheless, despite our best efforts, the teacher may still have differed in their teaching styles, thus possibly limiting to some extent the comparison of the instructed and control learners.

The four types of written CF were operationalized as follows. 
Table 2. four types of written CF

\begin{tabular}{lll}
\hline Component & Length & Aim \\
\hline $\begin{array}{l}\text { Week 1: } \\
\text { Consciousness } \\
\text { raising }\end{array}$ & 45 minutes & Raise awareness of form-function-context \\
& & mappings
\end{tabular}

\begin{tabular}{|c|c|c|}
\hline $\begin{array}{l}\text { Week 1: } \\
\text { Meta-pragmatic } \\
\text { explanation }\end{array}$ & 45 minutes & $\begin{array}{l}\text { 1. Explicitly teach email discourse, forms for } \\
\text { making requests and politeness strategies } \\
\text { (including } 4 \text { types of syntactic downgraders) } \\
\text { 2. Discuss politeness strategies students } \\
\text { would choose and pragmatic consequences of } \\
\text { the decision. }\end{array}$ \\
\hline
\end{tabular}

\begin{tabular}{lll}
\hline $\begin{array}{l}\text { Week 2-4: } \\
\text { Communicative }\end{array}$ & Three 90- minute & Practice and revise types of emails that were \\
practice & weeks, totalling 270 & type of emails.
\end{tabular}

minutes.

Students of all four treatment groups were required to do multiple drafting as a part of the instructional procedures. Studies have indicated that multiple revisions may provide opportunities for multiple corrections of the same problem, thus making the corrections more focused and effective (Ellis et al. 2008; Shintani et al. 2014). Three email writing practice tasks (each focusing on a different scenario, i. e. Appointment, Feedback, and Extension) were given to the students, who were required to do three rounds of revision. For each round, students received their writing with instances of inaccurate and/ or inappropriate language use addressed in the margin, corresponding to the $\mathrm{CF}$ type the group had been assigned to (see examples above). Teachers focused on problematic performance. related to discourse structure of the email, request forms, politeness and other general language usage. After unlimited time reading the feedback, students were required to rewrite based on clean copies of their original works given back to them. The revision cycle in each practice task is summarized below: Step 1: Students submitted their first drafts. Step 2: Teachers feedbacked and returned first drafts to students. Step 3: Students read feedback, revised their work and submitted the second drafts. 
Step 4: Teachers gave further feedback, based on whether the inaccurate/ inappropriate language use had been successfully addressed or not:

a) If the problematic language use had been successfully addressed, teachers gave positive feedback.

b) If the problematic language use had been unsuccessfully addressed, teachers feedbacked again (with the CF type previously assigned to each group) and students were required to further revise their work (step 2,3,4 repeated).

\section{Assessment tools}

A discourse completion task (DCT) comprising three request scenarios that had been previously taught to the students was used to elicit students' production of email requests. However, the level of imposition in each test scenario was adjusted to prevent students from memorizing from the practice tasks (see further detail in Nguyen et al 2015). There are two main reasons why a DCT but not naturally occurring email data was chosen. First, it is hard to control social and situational variables in natural emails, thus limiting the comparability of data (Yuan 2001). Second, it is almost impossible to gather a large enough pool of data for each of the three scenarios. Compared to naturalistic data, the DCT is believed to be more effective both in collecting a large amount of data and in allowing researchers to control variables (Beebe and Cumming 1985). Nonetheless we acknowledge that although written DCTs are suitable for eliciting written genres (Bardovi-Harlig 2010), it is likely that students do not write as they would do in reality. Thus claims from DCT data should be made with caution. The DCT was not empirically piloted. However, the validity and reliability of the instrument were ensured by selecting the scenarios reported to commonly occur in student-professor communication (Biesenbach-Lucas 2007). Thus, it was expected that the students were familiar with these scenarios and found it less difficult imagining themselves in the scenarios. With regard to assessment procedure, both of the control and treatment groups participated in the pre-test, immediate post-test, and two delay post-tests conducted at one and eight months after to detect retention of effects if any.

\section{Result}

Research question 1 asked the effects of each of the four types of CF on students' use of syntactic downgraders to mitigate the force of their email requests addressed to professors. 
Research question 2 asked which of the four CF types was more effective. We answered these questions by submitting the four sets of test scores (pre- and three post-tests) gained by the control and each of the treatment groups (see Table 4) to a mixed between-within ANOVA, after checking that the assumptions of normality of data and homogeneity of variances were met.

\begin{tabular}{|c|c|c|c|c|c|c|c|c|c|}
\hline & \multirow[t]{2}{*}{$\mathbf{N}$} & \multicolumn{2}{|c|}{ Pre-test } & \multicolumn{2}{|c|}{ Post-test 2} & \multicolumn{2}{|c|}{ Post-test 3} & \multicolumn{2}{|c|}{ Post-test 4} \\
\hline & & M & $S D$ & $M$ & $S D$ & $M$ & $S D$ & $M$ & $S D$ \\
\hline Control & 19 & 1.06 & 0.86 & 0.58 & 0.73 & 1.18 & 0.88 & 0.84 & 0.60 \\
\hline EF & 13 & 1.33 & 0.95 & 2.03 & 0.37 & 2.26 & 0.49 & 2.32 & 0.52 \\
\hline RF & 16 & 0.91 & 0.86 & 2.19 & 0.56 & 2.08 & 0.68 & 2.04 & 0.55 \\
\hline MF & 12 & 1.14 & 0.70 & 2.03 & 0.73 & 2.14 & 0.41 & 1.83 & 0.63 \\
\hline CR & 19 & 0.68 & 0.65 & 2.41 & 0.65 & 2.14 & 0.68 & 2.07 & 0.87 \\
\hline
\end{tabular}

Table 3. Descriptive statistics.

The results of the mixed between-within ANOVA test revealed a significant main effect for Time, Wilk Lambda $=0.55, \mathrm{~F}(3,73)=28.7, \mathrm{p}=0.000$, partial eta squared $=0.55$, suggesting an overall change in the students' scores across four time periods (pre-test, immediate post-test, one-month, and eight-month delayed post-tests). A significant main effect for Group was also found, $\mathrm{F}(4,74)=14.1, \mathrm{p}=0.000$, partial eta squared $=0.43$, suggesting a difference in the total scores of the five groups. In addition, the results revealed a significant interaction effect between Group and Time, Wilk Lambda $=0.48, F(12,190.8)=5.09, p=$ 0.000 , partial eta squared $=0.22$, suggesting the different patterns of change across time for the groups compared.

In addition, we also conducted a one-way repeated measures ANOVA with post hoc Bonferroni multiple comparisons to test the differences in scores across time for each group (see Table 5), and four one-way ANOVAs with post hoc Bonferroni multiple comparisons to test the differences among the five groups at the four different points in time (see Table 6). Looking at Figure 1 and the results of the additional tests to answer our research questions, it becomes clear that:

(i) while all the four treatment groups displayed a significant increase in their postintervention scores (gains observed at $\mathrm{p}<0.05$ in all three posttests for the CR and 
RF groups, and in one-month and eight-month posttests for the MF and EF groups respectively), such an improvement was not observed for the control group, who, in fact, significantly decreased their scores in the immediate post-test $(\mathrm{p}<0.05)$;

(ii) while there was no difference among the five groups in the pre-test measurement $(p>0.05)$, the control group lagged behind each of the treatment groups in all three post-tests $(\mathrm{p}<0.005)$.

\begin{tabular}{lrrrrrr}
\hline Group & F & Sig. & & & \multicolumn{2}{c}{ Cohen's d effect size } \\
\cline { 3 - 7 } & & & $\begin{array}{r}\text { Pre-test vs. } \\
\text { Post-test 1 }\end{array}$ & $\begin{array}{r}\text { Pre-test vs. } \\
\text { Post-test 2 }\end{array}$ & $\begin{array}{c}\text { Pre-test vs. } \\
\text { Post-test 3 }\end{array}$ & Average \\
\hline Control & 4.44 & 0.007 & 1.09 & 0.29 & 0.60 & 0.66 \\
EF & 10.07 & 0.004 & 1.56 & 1.73 & 3.01 & 2.10 \\
RF & 16.3 & 0.000 & 3.03 & 2.68 & 2.18 & 2.63 \\
MF & 5.36 & 0.004 & 1.88 & 2.29 & 1.45 & 1.87 \\
CR & 31.2 & 0.000 & 4.14 & 3.63 & 2.78 & 3.52 \\
\hline
\end{tabular}

Table 4. Results of the one-way repeated measures ANOVA conducted for pre-to-post gains by the control and treatment groups.

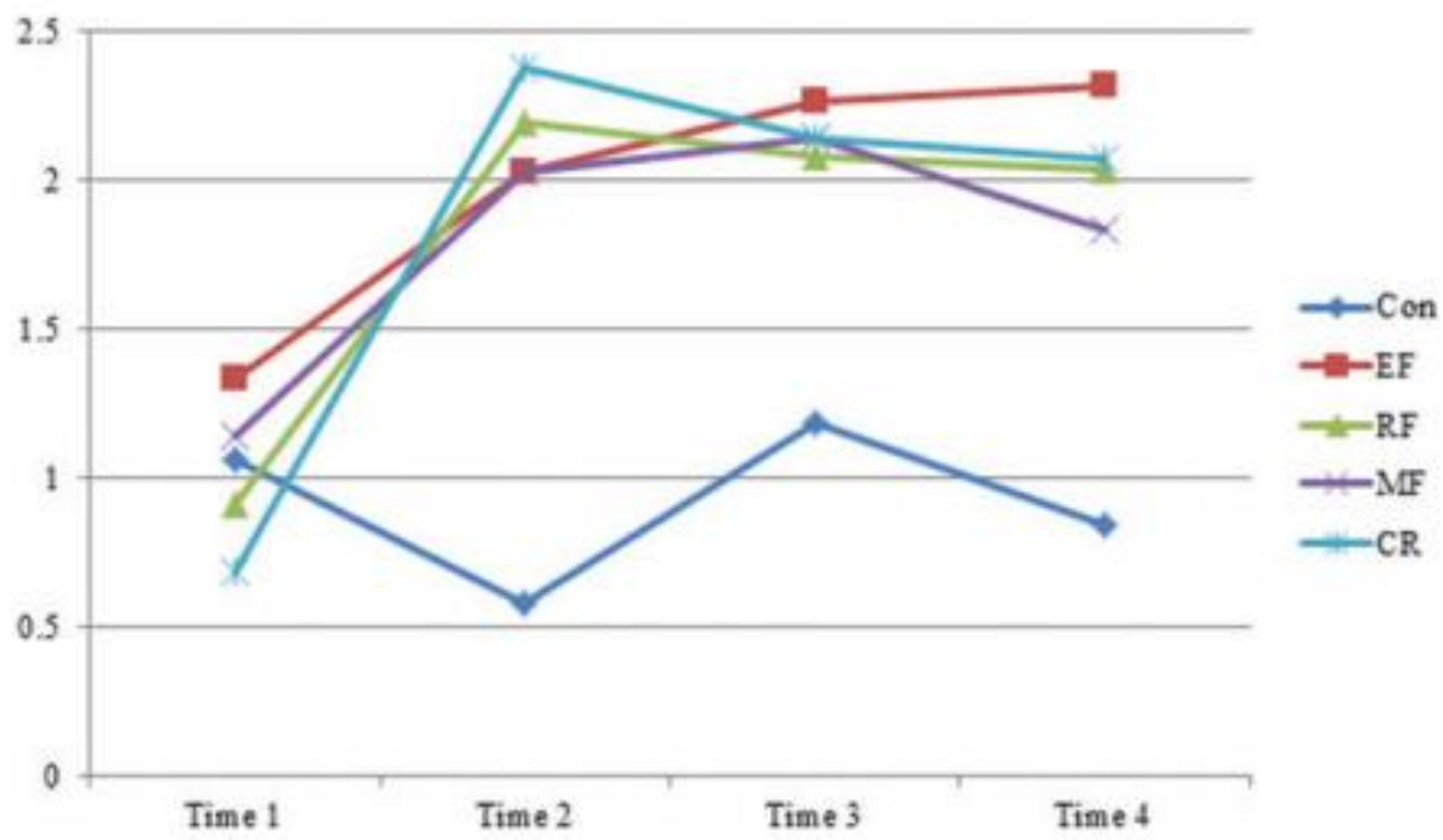

Diagram 2. Changes across time by the control and treatment groups. 
One of the problems related education and teaching is individual-psychological problem. The respondents stating to have faced mostly individual-psychological problems in their education prefer "active personal struggle" with emotional behavior as a way out from stress.

But the correlation between this method of fighting and personal-psychological problems is not meaningful at the level of 0.05 , that is $\mathrm{P}=0,115$. The respondents facing individualpsychological problems prefer to be self-regulated with cognitive processes as a way out from stress regarding this "support from outsight-connection with socium method. The correlation between the mentioned problem and this method is meaningful in 0,05 level. That means since $\mathrm{P}=0.037$ we can say that there is serious connection between these two factors (table 3 ).

\section{Conclusion}

The purpose of this study was to determine the effect of feedback in native and Persian language on reading and writing in bilingual students in a training complex in Tehran. The results showed that providing feedback in Farsi language had no significant effect on the reading and writing of bilingual students. This finding is consistent with research by Spiller (2009), Duncan (2007), Weaver [24] (2006), Moreno [25] (2004), Chanuk [26] (2000) and Williams [27] (1997), On the complexity and meaninglessness of the feedback, it is consistent. The findings of these studies attribute the ineffectiveness of feedback to its unclear expression and complexity and imply that feedback in official language is complex and ambiguous for bilingual students who are unfamiliar with the official language. It doesn't have the necessary educational impact.

Duncan (2007) believes that feedback from teachers is often provided with specialized, academic language and vocabulary that is meaningful to the teacher and does not convey any message to the student. In other words, feedback does not establish interaction between teacher and student and does not play a role in the student's connection to the classroom process. Such feedback does not, in Spiller's (2009) view, make any difference in student performance and behavior. According to Chanuk (2000), students often receive a feedback message different from what the teacher intended. To that end, feedback is needed to understand and understand the student.

Elementary students, especially students in multi-grade classes, understand at most basic levels the meaning, the concept, or the positive or negative direction of most common 
feedback from teachers. In multi-grade classes, higher grades students and students who repeat previous grades are the source of this information. In some situations, feedback is not dependent on the student's knowledge of the official language, but on the extent to which he or she is aware of the teacher's behavior, behavior and imitation. It seems that when feedback takes on a proprietary and unpopular form, the student has no choice but to speak the language in order to receive information. A language in which, unlike a mother tongue, is not sufficiently fluent. Sometimes oral corrective feedback is completely within the student's understanding. The vocabulary given in the feedback context is commensurate with the student's educational background but he / she is unable to receive the feedback message due to poor hearing in Persian. When the student is unaware of the feedback message, he or she tries to predict it by following the performance of others (classmates or peers), which in turn causes problems for him or her to adapt to the classroom environment (Sagerly, 2013). . For Weaver (2006), students find feedback useful and useful in providing a specific language and containing sufficient guidance. Moreno (2004) and Williams (1997) also believe that unclear feedback impedes learning and fails learners. Another finding showed that there was a significant difference in reading and writing between the group receiving feedback in the mother tongue and the control group. Significant differences were found between the first experimental group and the control group, with classroom feedback in Kurdish and native vocabulary for Kurdish language students, with research conducted by UNESCO (2001, 2005, 2007 and 2008 in the field of mother tongue-related education, and the findings of Lindholm-Leary, Lindholm-Leary and Borsato, Pasco and Verrago (2008), Cassanen (2005), Hawes (2002), Thomas \& Collier (2002), Benson (2002), Lindholm (2001), Cummins (2000), Datcher (1994), Van Click [41] (1994) and Ramirez, Yuen and Rami (1991), are consistent in this regard. According to these researchers, mother tongue-based education enhances academic achievement and enhances bilingual students' learning. Explaining this finding may be that feedback in the mother tongue has played an important role in the development of bilingual (Kurdish) students' reading, who have significant familiarity with their mother tongue vocabulary and sign systems.

It can be argued that feedback from native speakers has narrowed the gap in the approximate growth area. However, the teacher in this situation does not engage with the student problem solving process, but expresses the problem in a language that is understandable and specific to the student. This comprehensible language is the same as the student's native language, which seems to have silenced the reading process. 
Providing Kurdish feedback seems to have helped the Kurdish bilingual student to make a comparison between the teaching materials available in Farsi and the linguistic and cultural experiences in her native language, and thus better read reading assignments. Prior to this, no research directly examining the impact of feedback in the mother tongue has been conducted. There is also no research into the impact of native language measurement. Kassanen (2005), Benson (2002), and Hawes (2002) have addressed the benefits of mother tongue-based education. From their point of view, first language or mother tongue is the most effective language for primary education, and effective mother tongue education enables children to become more involved in school activities and to achieve better academic achievement. UNESCO (2001) proposes that continuing education with bilingual children and their first language interaction with their families and communities on more complex and transnational issues be promoted through formal formal education to enhance reading and reading skills. Writing in their first language and facing the positive attitudes of parents towards receiving mother tongue as a factor of cultural identity and for specific instrumental purposes. According to Dacher (1994), the best predictor of second language (formal language) development is the level of cognitive / academic skills in the first language (mother tongue). These research findings are in line with those obtained by Cummins (2000) and reported in research on the benefits of mother tongue-based primary education (UNESCO, 2008).

Since this study was conducted on bilingual students from a particular ethnic group, caution should be exercised in generalizing its findings to bilingual students of other ethnicities. Due to the tribal situation of the study community and the lack of familiarity with the texture of the teacher-made questionnaires that were designed to be somewhat long-lasting for the third grade elementary educational goals, the fatigue in answering the questionnaires is not unexpected.

The findings of this study provide useful information for teachers, parents and practitioners of the education system. Based on the results of this study, and similar previous studies, which show a positive and meaningful relationship between feedback and academic achievement (reading and writing), it is suggested that education officials, especially teachers, address various aspects of feedback in the process. Teaching - learning and measuring attention. Given the importance of mother tongue, and its role in education, especially in elementary school, it is suggested that content, materials, and educational planning be affected. The Iranian student community is made up of diverse ethnicities and cultures. Each of these ethnicities communicates in a different language of dialogue and creation. This indigenous and cultural 
diversity must be taken into account in the formulation of the national curriculum, and in the adaptation of educational content and textbooks for all Iranian students. On the other hand, the sensitivity of bilingual areas requires that teachers working in these areas have some familiarity with the native language and customs and traditions of the place of work in order to better communicate with students, and to transfer materials and educational content properly. Finally, it is suggested that future research be conducted among students of other ethnicities and in other educational levels.

\section{REFERENCE}

1. Akikawa, K. \& N. Ishihara. 2010. "Please write a recommendation letter": Teaching to write e-mail requests to faculty. In D. Tatsuki \& N. Houck (eds.), Pragmatics: Teaching speech acts (pp. 47-66). Alexandria, VA: Teachers of English to Speakers of Other Languages.

2. Alcón-Soler, E. 2005. Does instruction work for learning pragmatics in the EFL context? System 33(3). 417-435.

3. Alcón-Soler, E. 2007. Fostering EFL learners' awareness of requesting through explicit and implicit consciousness-raising tasks. In M. De Pilar Garcia Mayo (ed.), Investigating tasks in formal language learning, 221-241. Bristol: Multilingual Matters.

4. Alcón-Soler, E. 2008. Learning how to request in an instructed language learning context. Bern: Peter Lang.

5. Alcón-Soler, E. 2013. Mitigating email requests in teenagers' first and second language academic cyber-consultations. Multilingua 32(6). 779-799.

6. Alcón-Soler, E. 2015. Pragmatic learning and study abroad: Effects of instruction and length of stay. System 48. 62-74.

7. Bardovi-Harlig, K. 2010. Exploring the pragmatics of interlanguage pragmatics: Definition by design. In A. Trosborg (ed.), Pragmatics across languages and cultures, 219-260. Berlin: De Gruyter Mouton.

8. Barron, A. 2008. The structures of requests in Irish English and English English. In K. Schneider \& A. Barron (eds), Variational pragmatics, 35-68. Amsterdam: John Benjamins.

9. Antsyferova L. I. (1994). Personality in difficult living conditions: rethinking, transformation of situations and psychological protection / L. I. Antsyferova. // Psychological journal. No. 1, p.3-18

10. Martínez-Flor, A. 2008. The effects of an inductive-deductive teaching approach to develop learners' use of request modifiers in the EFL classroom. In E. Alcon (ed.), Learning how to request in an instructed language learning context, 191-225. Bern: Peter Lang.

11. Martínez-Flor, A. \& Y. J. Fukuya. 2005. The effects of instruction on learners' production of appropriate and accurate suggestions. System 33. 463-480. MartínezFlor, A., E. Usó-Juan \& A.

12. Fernández-Guerra. 2003. Pragmatic competence and foreign language teaching. Spain: Servei de Publicacions de la Universitat Jaume I, Castello. 
13. Nguyen, T.T.M. 2008. Modifying L2 criticisms: How learners do it? Journal of Pragmatics, 40 (4). 768-791.

14. Nguyen, T.T.M., T.H. Pham \& M.T. Pham. 2012. The relative effects of explicit and implicit formfocused instruction on the development of L2 pragmatic competence. Journal of Pragmatics 44 (4). 416-434

15. Nguyen, T.T.M., H. Do, T.A. Nguyen \& T. Pham. 2015. Teaching email requests in the academic context: A focus on the role of corrective feedback. Language Awareness, 24(2). 169-195.

16. Nipaspong, P. \& S. Chinokul. 2010. The role of prompts and explicit feedback in raising EFL learners' pragmatic awareness. University of Sydney Papers in TESOL 5. 101-146.

17. Salsbury, T. \& K. Bardovi-Harlig. 2000. Oppositional talk and the acquisition of modality in L2 English. In B. Swierzbin, F. Morris, M.E. Anderson, C.A. Klee \& E. Tarone (eds.), Social and cognitive factors in second language acquisition, 57-76. Somerville, MA: Casadilla Press.

18. Sheen, Y. 2010a. The role of corrective feedback in second language acquisition: An introduction to the special issue. Studies in Second language Acquisition 32(2). 169179.

19. Sheen, Y. 2010b. Differential effects of oral and written corrective feedback in the ESL classroom. Studies in Second Language Acquisition 32(2). 203-234.

20. Shintani, N., R. Ellis \& W. Suzuki. 2014. Effects of written feedback and revision on learners' understanding and use of two English grammatical structures, Language Learning 64(1). 103-131.

21. Swain, M. 1995. Three functions of output in second language acquisition. In G. Cook \& B. Seidlhofer (eds), Principles and practice in applied linguistics, 125-144. Oxford: Oxford University Press.

22. Taguchi, N. 2011. Teaching pragmatics: Trends and issues. Annual Review of Applied Linguistics 31. 289-310.

23. Taguchi, N. 2015. Instructed pragmatics at a glance: Where instructional studies were, are, and should be going. State-of-the-art article. Language Teaching 48. 1-50.

24. Takahashi, S. 2001. The role of input enhancement in developing interlanguage pragmatic competence. In K. Rose \& G. Kasper (eds.), Pragmatics in language teaching, 171-199. New York: Cambridge University Press.

25. Takahashi, S. 2005. Noticing in task performance and learning outcomes: A qualitative analysis of instructional effects in interlanguage pragmatics. System 3. 437-461.

26. Takahashi, S. 2010. The effect of pragmatic instruction on speech act performance. In A. Martínez-Flor \& E. Usó-Juan (eds.), Speech act performance: Theoretical, empirical and methodological issues, 127-144.

27. Amsterdam: John Benjamins. Takimoto, M. 2006. The effects of explicit feedback on the development of pragmatic proficiency. Language Teaching Research 10. 393-417.

28. Takimoto, M. 2009. Exploring the effects of input-based treatment and test on the development of learners' pragmatic proficiency. Journal of Pragmatics 41. 1029-1046.

29. Yuan, Y. 2001. An inquiry into empirical pragmatics data-gathering methods: Written DCTs, field notes and natural conversations. Journal of Pragmatics 33(2). 271-292.

30. Antipov V.V. (2004). Psychological adaptation to extreme situations / V.V. Antipov. :Vlados. Press, p.174. 
31. Arakelov, G. G. (2008). Stress factors affecting the formation of personality psychosocial stability during the student years / G. G. Arakelov, V. V. Arshinova, G. E. Zhdanova. // Psychological science and education. №2, p.52-60

\section{SOBRE OS AUTORES:}

\section{Farzaneh Sabokrouh}

$\mathrm{PhD}$ in TEFL, Department of language, University college of Rouzbahan, Sari, Mazandaran,Iran. E-mail: farzanehsabokrouh@yahoo.com

iD http://orcid.org/0000-0001-6048-1086

\section{Nasrin Shamsipour}

Department of Language and linguistics, Sharif university of Technology, Tehran, Iran. Email: Nasrinshamsipour26@gmail.com

iD http://orcid.org/0000-0002-3488-5367

\section{Vahideh Rastgoo}

PhD Student in TEFL, Isfahan Branch, Islamic Azad University, Isfahan, Iran. E-mail: v.rastgoo72@gmail.com

D http://orcid.org/0000-0003-0651-7126

Recebido em: 15 de novembro de 2019 